\title{
Urban ecosystems of Kurukshetra, India, an amalgamations of eco-friendly, historical as well as archaeological adverse facades: A case study
}

\author{
PremK umari Gupta \\ Department of Chemistry, Indira Gandhi National College, Ladwa -136132 (Kurukshetra), INDIA \\ E-mail:pguptaign@gmail.com \\ Received: August 28, 2012; Revised received: September 11, 2012, Accepted: November 10, 2012
}

\begin{abstract}
Kurukshetra, a state of India is a historical place having global significance linked with its multifaceted aspects concerning education, science education, engineering colleges, museums and above all some sites and spots which are witnesses to the events of world famous war namely, "Mahabharata". The studies reveal that urbanization processes have turned rural Kurukshetra into a modern semi-urban area with distinct urban features by creating "Urban Estates". This is an activity which has two faces: Eco-friendly face and adverse ecological face. The generation of an attraction, ultra modern city equipped with vast green belts; impressive avenues having intense plantations of trees, bushes and profusely dotted with Civil Parks is a phenomenal change. One of the most impressive eco-friendly façade of the new environs is the ambience presence of orchards and plant nurseries and there is practice of "Kitchens-Waste" disposal which is disposed off at a safe place to convert it into organic manure. The best of sanitary conditions are in place which is one more environment friendly aspects. A very well laid out "Mini-Secretariat" encompassing virtually each and every office of the District Administration is intensely covered by very thick cover of trees and a new experiment, pioneered first by Haryana Govt.However, the negative features are many to negate the over all positive features. Foremost is related with discarding the traditional and endemic trees like Shisham Dalbergia sissoo, Neem Azadirachta indica, Beri Morus alba, Peepal Ficus religiosa, Banyan Ficus benghalensis and Mango Mangifera indica trees for tree plantations in favour exotic varieties.
\end{abstract}

Keywords: Archaeological, Facades, Historical, Kurukshetra, Urban ecosystem

\section{INTRODUCTION}

India is an oriental civilization having its roots in Induscivilization Harappa civilization in Taxilla city, located now in so called Pakistan. Haryana province in India falls in National Capital region of New-Delhi surrounding it on at least three sides Kurukshetra town, the locus of present investigations is situated on Indian National Highway No.1 (Ground Trunk Road/Sher Shah Suri Marg) at a distance of $157 \mathrm{Kms}$ North of New Delhi and considered as the cultural and educational Capital of Haryana (30 $44^{\prime} \mathrm{N} 76^{\circ} 47^{\prime} \mathrm{E} 30.73^{\circ} \mathrm{N} 76.78^{\circ} \mathrm{E}$ ).

In context of present studies, it is relevant to bring on record here that Haryana used to be an extremely backward province up to 1966 and today, perhaps it is one of the most prosperous State of modern upcoming nation i.e. India. In this very context, it is to be mentioned that at the time of Haryana's birth in 1966, there were few towns of reasonable size and reputation like Faridabad, Karnal, Panipat and Ambala which in turn had no standing vis-à-vis Amritsar, Jalandhar, Ludhiana and Patiala of Punjab. However, today Haryana has Gurgoan having international status in "IT" and Ambala city for its scientific goods and electric mixtures machine. If that is so, Kurukshetra town is known on national and international levels for its rich culture and historical past along with a hub of higher education. Kurukshetra town today is transformed marvel of tourist attractions having some globally acclaimed centres of tourist attraction. An agency, namely Haryana Urban Development Authority (HUDA) has played a pivotal role in adding new schemes to the landscape and environment of Kurukshetra by establishing new human inhabitations in the shape of Housing Board Colonies and Urban Estate Sectors(Sectors 13, 7, 8, 5, 2, 3 and 300) modern shopping malls(Sector 17, 10 etc.). As such an analysis of new Kurukshetra town brings to the fore a scenario where one witnesses an amalgamation of eco-friendly and adverse anti-environment facades mixed with typical rural scenes. One also finds eye soothing greenery and eyesores in the shape of vast graveyard of polythene bags. In the present studies, attention is focused to discover its components, good and bad, as a case study, in context of a developing economy like India. Various workers have so far focused attention on varied aspects of urban planning in India. Few important workers include, amongst others, Wood (1958), Mukerjee and Singh (1962), Gore (1971), Das (1981), Nath (1988), Priya (1993), Krishna Menon(1997), Shaw (1998), Davy (1999) and Sharma et al. (2000). 
However, no research work has been done in context of Kurukshetra and hence the present study was undertaken. The objective of the study was to find out environment friendly and adverse features in the façade of a new vibrant urban location i.e. Kurukshetra, a state of India.

\section{MATERIALS AND METHODS}

It has been endevoured to take stock of the overall environs of Kurukshetra town in Haryana province in India, vis-à-vis environment friendly practices and those ones which have contributed towards the deterioration and abuse of environment. As such, the present studies have been done in an area of $100 \mathrm{Sq}-\mathrm{Kms}(10 \mathrm{Km} \times 10 \mathrm{Km})$ in and around Kurukshetra town in India. Its geographical position is $29^{\circ} 59^{\prime} \mathrm{N} 76^{\circ} 49^{\prime} \mathrm{E}$. Kurukshetra town of today is, in effect, the battle field of Mahabharata War spread over $84 \mathrm{Kms}$ (approximately $160 \mathrm{Kms}$ across) fought between Pandavas and Kauravs under the veteran war Lords and Gurus like Lord Krishna, Bhisma Pitamah, Duryodhan etc. Actually, Kurukshetra town is the satellite town to Thanesar-town another historical place in the history of India. Extensive forays and surveys have been done in the last 5 years (2006-2011) in various parts of the study area to do observations. Extensive photographic account has accumulated and the same is analyzed, interpreted to reveal good environment friendly practices and those which are a scar on the façade of environment.

\section{RESULTS AND DISCUSSION}

India has changed dramatically towards the propagation and adsorption of relevant environment friendly societal behavioral patterns which are aimed to sustainable development and inclusive growth of her large population of over 121 cores. A brief synopsis of environment friendly urban ecosystem's salient features has been computed in Table 2 as an attempt to simplify, demonstrate and illustrate the positive facades of urban ecosystem in India. The landscape across the territorial boundaries of Kurukshetra and Thanesar satellite town in Haryana province in India has been upgraded in an impressive way enhancing the scope of civic sense, preservance of cultural heritage by further embellishing the precincts with beautiful shady and flower bearing trees, wines, exotic trees varieties(Table 1).

The ambience of herbal Parks, Public Parks, Modern districts level mini-secretariat, maintenance of large water bodies like Brahmsarovar on scientific lines creation of recreation centres as Museum (Cultural and Scientific), Libraries, Kalpana Chawla Planetarium, light and Sound Mahabharata war-depiction; 4 lanes-tree lined long avenues, mast-light poles are some recently created infrastructures created in rural India, which only 20 years back, was considered as backward. All these features are not only directed at upgrading the life styles of a common citizen but also, above all., very environment friendly features indicating inclusive growth based on the concept of sustainable development.

The amalgamated environmental Kurukshetra town is better explained by Tables 1 and 2 wherein composite facades are explicit embodying eco-friendly as well as ecological disastrous features. To set forth the ecofriendly features of Kurukshetra town is the presence of a vast wetland as Brahmsarovar multiple presence of numerous well maintained civil parks, well maintained herbal park, vast water body on national highway no. 1 very near to sector 30(Tables 1 and 2). The ecological disastrous features include several spots where age old wetlands have been encroached upon after surreptitious land filling operations (Tables 1 and 2). The esthetically positive façade is provided by the newly created Jindal Park which is an "A Grade Park" along with its creation on a piece of land which used to be a sore by way of harbouring dirty sludge hyacinth growth and swines in plenty (Table 1).

Tourism facades is imparted by the presence of Kalpana Chawla Planetarium, Shri Krishna Museums, National Science Museum (Table 1), thus added one positive esthetic feature to the environs of very young town of Kurukshetra. The archaeological face is imparted by the discovery of MOHAN-JO-DARO time civilization at HARI-KA-TILLA. The Excavations were done here in 1980s and 1990s. The negative features in the environment related aspects of Kurukshetra are just like few drawbacks even in Le-Corbusier city of Chandigarh which is the pride of India (Davy, 1999). Based upon the eco-friendly features, it seems planners of Haryana Urban Development Agency (HUDA) have based their concept on the relations developed by earlier city-planners in India and abroad in their bid to focus attention on giving significance to eco-friendly ingredients and components in their overall urban- architectural planning in India. (Wood, 1958; Mukerjee and Singh, 1962, Gore, 1971, Das, 1981, Nath, 1988, Priya, 1993, Krishna Manon, 1997, Shaw, 1998, Davy, 1999 and Sharma et al., 2000)

On the other hand, everything is not good with the Kurukshetra environs as is evident from Table-2. As, anywhere in the oriental world, civic sense is rubbishy poor in Kurukshetra. The sector 2 ground is a filthy grave yard of used up rejected polythene bags which is a proof of Indians' cipher interest managing the premises and outskirts of human inhabitations. Villages are stark and nude examples of hellish conditions prevailing in streets of villages due to piling of slush, anywhere and everywhere. The situation is no different in Thanesar town, and specially Pipli village in Sector 2 in Kurukshetra. Indians in the past used to conserve village ponds. However, today ponds have turned into bowls of 
Table 1. Depiction of environment friendly practices in a typical urban ecosystem in Kurukshetra town in Haryana, India

\begin{tabular}{|c|c|c|}
\hline S. No. & Name of spot & Comments \\
\hline 1 & $\begin{array}{l}\text { Devi Las Community Park in Sector-3, } \\
\text { NH-1 in Pipli. }\end{array}$ & $\begin{array}{l}\text { A huge park with big grassy patches and tree lined avenues a } \\
\text { good place of morning/evening walks by residents. }\end{array}$ \\
\hline 2 & $\begin{array}{l}\text { Brahmsarovar complex maintained by } \\
\text { Kurukshetra Development } \\
\text { Board(KBD) }\end{array}$ & $\begin{array}{l}\text { A huge water reservoir with intense afforested landscape, } \\
\text { soothing effect provider to visitors a good civic marvel. }\end{array}$ \\
\hline 3 & $\begin{array}{l}\text { Skeikh Chilli Ka Makbara maintained } \\
\text { by archaeological survey of India }\end{array}$ & $\begin{array}{l}\text { A eye soother to visitors with a palatial counterpart of Taj- } \\
\text { Mahal in Haryana. Well maintained greenery for good } \\
\text { environment. }\end{array}$ \\
\hline 4 & Herbal Park Near Jyotisar & $\begin{array}{l}\text { A good messenger for patronizing medicinal plants in daily } \\
\text { life: a very good example of making people environment } \\
\text { friendly by favoring flourishing medicinal herbs, shrubs and } \\
\text { trees. }\end{array}$ \\
\hline 5 & Narwana Irrigation Canal & $\begin{array}{l}\text { Near jyotisar complex. A good lesson provider for } \\
\text { harvesting water in reservoirs for electricity generation and } \\
\text { subsequently using the water for irrigation through canals. } \\
\text { Pro-environment and Pro-development use of a natural } \\
\text { resource. }\end{array}$ \\
\hline 6 & $\begin{array}{l}\text { Dozens of small sized Public Parks in } \\
\text { Urban Estate. }\end{array}$ & $\begin{array}{l}\text { Provides facilities for morning walk, evening walk at } \\
\text { doorsteps for tension loaded society. A lesson for public to } \\
\text { grow grass in appropriate places. }\end{array}$ \\
\hline 7 & $\begin{array}{l}\text { Om Parkash Jindal Memorial Public } \\
\text { Park }\end{array}$ & $\begin{array}{l}\text { An example of reclamation of dirty ditches filled with } \\
\text { sewer-power into a marvelous public Park with multitude of } \\
\text { environment friendly activities like vast patches of green } \\
\text { lawns variety of entertainment and environment awareness } \\
\text { facilities. }\end{array}$ \\
\hline 8 & $\begin{array}{l}\text { Judiciary Complex, District Police } \\
\text { Headquarters, Mini Secretariat }\end{array}$ & $\begin{array}{l}\text { Most modern Govt. of Haryana (India) Administration } \\
\text { district headquarters. A good example of good environs with } \\
\text { proper civic sense }\end{array}$ \\
\hline 9 & Ayurvedic college Herbal Garden & $\begin{array}{l}\text { A good, environment friendly gesture to propagate the idea } \\
\text { of growing herbal plants for medicinal use }\end{array}$ \\
\hline 10 & $\begin{array}{l}\text { Jindal Park, Jhansa road, Thanesar } \\
\text { (Kurukshetra) }\end{array}$ & $\begin{array}{l}\text { It was a sore in the environs of Kurukshetra environs whose } \\
\text { mosquitoes and worms used to rule the roost in the presence } \\
\text { of swines hyacinth today. It is a park, par excellence. }\end{array}$ \\
\hline 11 & Kalpana Chawla Planetarium & One excellent aesthete face of environs in Kurukshetra \\
\hline
\end{tabular}

stinking water at the very steps of households in village Sunderpur in Kurukshetra in Sector-05(Table-2). Gore (1997) has also emphasized the crucial role of social aspects of urban planning.

In conclusion, one may say that as per the studies, Kurukshetra Urban Ecosystems is an amalgamation of good environmental practices in the accompaniment of hellish conditions. In contrast, Krishna Manon (1997) could not confront such extra ordinary paradoxes in Urban Planning. It is certainly a unique feature of Kurukshetra Urban Ecosystems. More or less Kurukshetra urban Ecosystems are extrapolations of
Chandigarh city designed by Le-corbusier (Davy, 1999; Gore, 1971 and Das, 1981). It is borne out of the present studies that Haryana states, Haryana Urban Development Agency's various projects may invite the attention of the other provinces of India in respect of creating ecology -friendly townships. The concept be extended to poor states like Rajasthan, Jharkhand, Chhattisgarh and Uttrakhand. Rejected patches of land where no agriculture practices are in place may be promoted as world class human residing places having environmental friendly facades. Moreover, such new projects be mixed with cottage industry, small scale 
Table 2. Depiction of environment degrading factors in a typical urban ecosystem in Kurukshetra town in Haryana, India.

\begin{tabular}{|c|c|c|}
\hline S.No. & Name of Spot & Comments \\
\hline 1 & $\begin{array}{l}\text { Outskirts of Urban Estate in } \\
\text { Sector-2 Kurukshetra, India }\end{array}$ & $\begin{array}{l}\text { Huge piles of rejected polythene bags shaping the environs in } \\
\text { graveyard of un-cared-for polythene bags }\end{array}$ \\
\hline 2 & $\begin{array}{l}\text { A vast water body nearby } \\
\text { sector-30, Kurukshetra, India }\end{array}$ & $\begin{array}{l}\text { An example of deliberate attempt to eliminate water body. A bad } \\
\text { aspect against the nature. }\end{array}$ \\
\hline 3 & $\begin{array}{l}\text { Entire complex of Urban } \\
\text { Estate, Kurukshetra Sector- } 2 \\
3,5,7,8,10,17 \text { and Sector } 30 \text {. }\end{array}$ & A negative example of urbanization on a highly fertile land \\
\hline 4 & $\begin{array}{l}\text { Remains of Saraswati River in } \\
\text { and around Thanesar city, } \\
\text { nearby Kurukshetra }\end{array}$ & $\begin{array}{l}\text { Once a vibrant river in past time, a historical river which is extinct } \\
\text { now, its shallow depressions today are no more than bosom } \\
\text { harboring stagnant sewer water. Mosquitoes breed here. A negative } \\
\text { practice against environment. }\end{array}$ \\
\hline 5 & $\begin{array}{l}\text { Open air Wheat/Rice Grain } \\
\text { Storage Godowns of Food } \\
\text { Cooperation of India (FCI) } \\
\text { Govt. Of India in sector } 02 \text {. }\end{array}$ & $\begin{array}{l}\text { Precious grains (Wheat/Rice) are stored in a most careless manner. } \\
\text { These grains have been procured by Govt. agencies at exaggerated } \\
\text { prices form farmers against the rules of market economy. Also, } \\
\text { farmers have used subsidized fertilizers, electricity and free ground } \\
\text { water in growing these grains. This huge un-cared -for heap of } \\
\text { bags of cereals tells a silent story of environment and natural } \\
\text { resources exploitation by society at the behest of political policies. }\end{array}$ \\
\hline 6 & $\begin{array}{l}\text { Sunderpur Village traditional } \\
\text { village pond }\end{array}$ & $\begin{array}{l}\text { A very vast and self sustaining healthy pond besides a Hindu } \\
\text { Temple now in doldrums due to illegal encroachment, it is a death } \\
\text { of a very beneficial natural wetland which used to receive entire } \\
\text { rainy water of the village thus indirectly helping recharging ground } \\
\text { water. It is anti-ecological phenomenon. }\end{array}$ \\
\hline 7 & $\begin{array}{l}\text { Yadav Dharamshala Rao-Thula } \\
\text { Ram Marg, Pehowa Road, } \\
\text { Kurukshetra }\end{array}$ & $\begin{array}{l}\text { It was a very vast natural pond which would harvest rainy water in } \\
\text { a very effective way, but only } 10 \text { years ago. Not now, as it is } \\
\text { completed illegally encroached upon by one and all. }\end{array}$ \\
\hline
\end{tabular}

industry and export oriented industries. It will be a new looks on environment, environment related issues encompassing positive faces of jobs generation of economic activities, wealth and foreign and foreign exchange.

\section{ACKNOWLEDGEMENTS}

Author is grateful to authorities of Kurukshetra University for providing necessary official support.

\section{REFERENCES}

Das, B. (1981). Urban planning in India, Social Scientist, 8(12): 53-67.

Davey, P. (1999). Celebrating Chandigarh- flaws in Le Corbusier's design of government buildings in Chandigarh, India. In Architectural Review, by Peter Davey.

Gore, M. S. (1971). Urban planning and Some Questions of Social Policy, E conomic and Political Weekly, 6(30/32): 1619$1621+1623+1625-1626$.
Krishan Manon, A. G. (1997).Imaging the Indian City, E conomic and Political Weekly, 32(46): 2932-2936.

Mukerjee, R. and Singh, B. (1962). Social Profiles of a Metropolis. Social and Economic Structure of Lucknow, Capital of Uttar Pradesh, 1954-56, Radhakamal by Mukerjee and Baljit Singh Source: The J ournal of Asian Studies, 21(4):583-584.

Nath, V. (1988). Regional Planning for Large Metropolitan Cities: A Case Study of the National Capital Region, E conomic and Political Weekly, 23(5):201-214.

Priya, R. (1993).Town Planning, Public Health and Urban Poor: Some Explorations form Delhi. Economic and political Weekly, 28(17): 824-834.

Sharma, Kavita, Sethi, C. K., Meeta and Rajiv lochan (2001). Brief History of a planned city. Economic and Political Weekly, 36(18): 1521-1523.

Shaw, A. (1999). Emerging Patterns of Urban Growth in India. E conomic and Political Weekly, 34(16/17): 969-978.

Wood, J. (1958). Development of Urban and Regional Planning in India. Land Economics, 34(4): 310-315. 